\title{
Monitoring the Changes of the Chemical and Physical Properties of the Planted Soil with Bean (Phaseolus Vulgaris) Plants under the Influence of Nano-Silica Treatments
}

\author{
Abdullah Hassan Al-Saeedi ${ }^{1}$
}

\begin{abstract}
This experiment was conducted in the green house at the Agricultural and Veterinary Training Research Station, King Faisal University, Al-Hassa, Saudi Arabia in the season of 2016-2017, to study the effects of different suspension of five rates of Nano-silica $(0,100,200,300$ and $400 \mathrm{mg} \mathrm{kg}^{-1}$ soil) which added to the soil before cultivation of bean plant on some chemical and physical properties of the soil. Complete block design with three replications was used in this experiment. The results indicated that the nano-silica rates have significant effect on percentage of sand, Silt, and clay particles, cation exchange capacity (CEC), particle density, porosity, saturation percentage, and surface area but has no significant effect on bulk density. All physical and chemical characters increased with increasing nano-silica rates except the bulk density, sand, EC, soluble $\mathrm{Ca}^{2+}$ and soluble $\mathrm{Mg}^{2+}$ decreased with increasing nano silica rates. Also, total nitrogen and the yield of bean crop increased with the increase of nano silica (NS) treatments up to $200 \mathrm{ppm}$ and then decreases with increasing NS at 400ppm.
\end{abstract}

Key words: Nano silica, CEC, pH, bean (Phaseolus vulgaris), particle density, porosity, crop yield

\section{INTRODUCTION}

Water security in Saudi Arabia is limited, weak and non-renewable. The agricultural sector consumes about $80 \%$ of usable water in Kingdom of Saudi Arabia. The agricultural sector in the world and Saudi Arabia seeks to raise the efficiency of water use through modern irrigation techniques or the use of soil conditioners such as chemically produced polymers as well as Nanotechnology such as nano-silica to reduce pressure on water from the agricultural sector. The first introduced the idea of nanotechnology was Feynman as, 1960 and this technology then progressed significantly in all sciences. Nanoparticles with extremely high reactivity and deliverability can be applied as amendments to improve soil quality, mitigate soil contaminations, ensure safe land-application of the conventional amendment materials (e.g., manures and biosolids), and enhance soil erosion control (Liu and Lal, 2012). The impact of nanotechnology and its miraculous performance are still undiscovered in geotechnics area (Zhang et al., 2004) and in the agricultural branches. Agricultural application of nanoparticles is cur rently an area of wide interest (Karunakaran et al., 2013). The introduction of nanoparticles into plants might have significant impact and thus, it can be used for agricultural applications for better growth and yield (Yuvakkumar et al., 2011). In another filed, Mohammadi and Niazian, (2013) indicated that the use of nano-technology in agricultural science and its application in tillage for improving the physical properties and mechanical issues will be improved soil structure, porosity, soil aggregates and modified the physical characteristics. The nanoparticles are very small amounts in soil, but it has more significant effect on soil due to their features such as high surface area, surface charge (appearance) and sometimes porous nano-engineering of physicalchemical properties of soil.

Nano-silica is an important metal oxide and is one of nanoparticles using in the many areas of the science that covers all major fields of science and technology including industrial, electronics, biomedical applications and as soil improvement component that changes the quality of soil materials (Paulkumar et al., 2011; Dinda et al., 2012).

Plants generally require silica to control biotic and a biotic stress (Ma, 2004). The presence of silicon reduces toxic metal elevation and increases water use efficiency and photosynthesis rate in plants. Furthermore, silicon also acts as a bio protectant against fungal attack (Datnoff et al., 1997). Currently, different sources of silica are used as fertilizer for crop, but their effect on soil chemical and physical properties is still not clear. These sources are routinely applied for promoting the growth of crops such as sugarcane and rice [Ayres, 1966; Epstein, 1999; Savant et al., 1999).

Many of studies indicated the using nano-silica as nanoparticles has the ability to improve the physical and chemical properties of the soil which reflection on the environmental media of plant growth. Karunakaran et al., (2013) mentioned that agricultural application of nanoparticles is currently an interesting area of production of crops. Also, the addition of nano-silica in soil enhances growth of maize, cucumber and beans (Yuvakkumar et al., 2011). 
Even though different sources of silica are used as silicon fertilisers, eco toxicological properties and the risks of silicon fertilizers in terms of soil microbial health and soil nutrient values are found to be scanty to the best of our knowledge. It is well known that plant growth promoting rhizobacteria (PGPR) plays a key role in recycling and maintenance of soil health which improves plant growth (Khakipour et al., 2008; OrtízCastro et al, 2008; Gholami et al., 2009) .

The investigations of Xiaochuan and Kai (2014) on the effects of nano-silica on the physical and mechanical properties of silty clay soil through scanning electron microscopy and a series of tests measuring specific gravity, liquid and plastic limits, uniaxial compression, and frost heave indicated that increasing nano-silica concentration increased the plastic and liquid limits of the clay as well as its uniaxial compression strength, but decreased the amount of frost heave produced. However, there was no change in the specific gravity of the clay sample. Further, nano-silica had no effect on the composition of the clay sample but reduced its average pore size, making its structure uniform.

Mohammadi and Niazian, (2013) indicated that the mechanical tillage practices on soil preparation improve soil structure, increase in porosity, better distribution of soil aggregates and eventually modify the physical properties of soil whereas the use of nano-technology in agricultural science and its application in tillage for improving the physical properties and mechanical issues has grown substantially. However the nanoparticles are very small amounts in soil, due to the features, the physical-chemical properties of soil are affected significantly by nano particle application. Small developments on the use of Nanoparticles to improve soil quality and land reform have been taken (Theron et al., 2008). Nano-silica particle effects were examined for increasing resistance against penetration and consolidation (Noll et al., 1992). The use of silica nanoparticles increaseed adhesion and reduce viscosity, and it seemed that the properties of the particles were depended on addition nano-silica (Mohammadi \& Niazian, 2013). The application of nanomaterials in soil showed that the increase $\mathrm{pH}$ and soil fertility, improved soil physical structure, and reduced mobility, availability and toxicity of heavy metals and other environmental factors and those that will stabilize soil components and subsides the erosion in the mining pick, (Lal, 2008). In agriculture, the soil conditioner studies have shown that nanoparticles can mine the soil quality by increasing water-holding capacity, increasing silt and clay and improve levels of nutrients, and eliminate toxins, (Liu and Lal, 2012).
Studies on the effect of Nano-silica is limited. Therefore, this study is concerned with studying the effect of different rates of nano-silica on some of the physical and chemical properties of soil, in addition to the bean crop.

\section{MATERIALS AND METHODS}

Field experiment: Green-house experiment was carried out at Agricultural and Veterinary Training Research Station, King Faisal University, Al-Hassa, Saudi Arabia in the season of 2016-2017. The soil of the experimental site was sandy clay loam, having $\mathrm{pH}(7.5)$, EC $\left(1.3 \mathrm{dS} \mathrm{m}^{-1}\right)$, OM $(0.05 \%)$, and total $\mathrm{N}(105 \mathrm{ppm})$. Random complete block design with three replicates was used to conduct in green-house. Five rates of Nanosilica (0 (NS0), 100 (NS100), 200 (NS200), 300 (NS300) and 400 (NS400) $\mathrm{mg} \mathrm{kg}^{-1}$ soil) which added to the soil before cultivation of bean plant. Fertilizers were supplied for cropping in the same amounts; before transplanting of bean seedling, the soil was mixed with NPK as basal dose according to the farm practice in the area. The distance between rows was $75 \mathrm{~cm}$ and between each two plants in the same row was $50 \mathrm{~cm}$.

Collection of soil samples: The soil samples were collected from surface 0-50 cm depth after harvesting of beans yield in green house at the Agricultural and Veterinary Training Research Station. The soil was treated with different suspensions of nano-silica before cultivation. Complete block with three replications was used in this experiment.

Preparation of Nano-silica suspensions: Using soil field capacity and weight of the soil at $0-50 \mathrm{~cm}$ depth, the content of the suspensions were calculated according the following equation:

\section{Soil weight $(\mathrm{g})=$ bulk density $*$ Soil depth $(\mathrm{cm}) *$ Area of plant $(100 \mathrm{~cm} *$ $100 \mathrm{~cm})$ \\ Added water as suspension form $=$ soil weight * moisture content at field capacity}

The nano-silica was used to prepare different rates 0(NS0), 100(NS100), 200(NS200), 300(NS300) and 400(NS400) mg nano-silica $\mathrm{kg}^{-1}$ soil.

Soil chemical analysis: Twelve soil unit samples were used from one $\mathrm{m}^{2}$ of $0-50 \mathrm{~cm}$ deep soil for physical and chemical analysis after harvest the yield. The soil samples were air dried, ground, and sieved through 2 $\mathrm{mm}$ for analysis. In saturation soil past extraction, the $\mathrm{pH}, \mathrm{EC}, \mathrm{Ca}^{2+}, \mathrm{Mg}^{2+}, \mathrm{Na}^{+}$, SAR (sodium adsorption ratio) were determined.

Total N, soluble silicon ( $\mathrm{Si}$ ) and cation exchange capacity (CEC) were measured according to Page et al. (1982). 
Soil physical analysis: Some physical properties such as sand $\%$, silt $\%$, clay $\%$, bulk density $\left(\mathrm{g} \mathrm{cm}^{-3}\right)$, prosily $(\%)$, saturation percentage $(\%)$, particle density and surface area $\left(\mathrm{m}^{2} \mathrm{~kg}^{-1}\right)$ were determined according to the methods are mention in Klute et al. (1986).

Infiltration rate, bulk density and total porosity were also measured at the beginning and end of growing season. In order to measure infiltration rate, double ring infiltrometer was used. The inner and outer rings were 30 and $50 \mathrm{~cm}$ in diameter, respectively, and the height was $35 \mathrm{~cm}$. The Infiltration test data were analyzed and the related Kostiakov equation for infiltration rate and cumulative infiltration were determined as follows:

$I=a t b$

where: $I=$ infiltration rate $(\mathrm{cm} / \mathrm{h}), t=$ time $(\mathrm{min}), a$, $b=$ coefficient and exponent, respectively

$F=m t n$

where: $F=$ cumulative infiltration $(\mathrm{cm}), m, n=$ coefficient and exponent, respectively

Statistical analysis: The obtained data were statistically analyzed using SAS software package (SAS, 2001) and the least significant differences (LSD) test was used to compare the differences among treatments means as illustrated by Steel and Torries (1980).

\section{RESULTS AND DISCUSSION}

Nano-silica impacts on physical and chemical properties: Table (1) showed the variance analysis of the sand, silt, clay, bulk density and porosity of the soil after harvest of bean under the effect of different rates of nano-silica amendment. The results revealed significant differences due to applied nano-silica among sand $\%(\mathrm{p}<0.001)$, silt $\%(\mathrm{p}<0.05)$, clay $\%(\mathrm{p}<0.001)$ and porosity $\%(\mathrm{p}<0.001)$ of the soil), while the differences were not significant for bulk density $\left(\mathrm{g} \mathrm{cm}^{-}\right.$ ${ }^{3}$ ) characteristic. These findings are consistent with the results found by Kim (2012) where pointed to the nanoparticle have often exhibit novel and significantly changed physical, chemical, and biological properties of the soil.

Fig 1 $(a, b, c)$ illustrated that the suspension of Nanosilica application has significant effects on the percentages of sand $(\mathrm{p}<0.001)$, silt $(\mathrm{p}<0.05)$ and clay

Table 1. Mean of square of sand, silt, clay, bulk density and porosity of the soil under the effect of different rates of Nano-silica amendment and after harvest of bean

\begin{tabular}{llccccc}
\hline Source of variance & $\begin{array}{l}\text { Degree of } \\
\text { freedom }\end{array}$ & $\begin{array}{c}\text { Sand } \\
\text { \% }\end{array}$ & $\begin{array}{c}\text { Silt } \\
\text { \% }\end{array}$ & $\begin{array}{c}\text { Clay } \\
\text { \% }\end{array}$ & $\begin{array}{c}\text { Bulk density, } \\
\mathbf{g ~ c m}^{-3}\end{array}$ & $\begin{array}{c}\text { Porosity } \\
\text { \% }\end{array}$ \\
\hline Replication & & 0.0265 & 0.0055 & 0.0026 & 0.0051 & 0.2460 \\
Nano silica treatment & 4 & $3.4458^{* * *}$ & $0.0329^{*}$ & $3.0639^{* * *}$ & $0.0012^{\mathrm{NS}}$ & $15.9702^{* * * *}$ \\
Error & 8 & 0.0676 & 0.0076 & 0.0157 & 0.0011 & 0.5459 \\
\hline
\end{tabular}

$* * *, * * *, * * * *$ : significant at $\mathrm{p}<0.05, \mathrm{p}<0.01, \mathrm{p}<0.001$ and $\mathrm{p}<0.0001$ levels of probability, respectively.

NS: not significant at $\mathrm{p}<0.05$ $(\mathrm{p}<0.001)$ particles, respectively. The results revealed that the sand percentage decreased with increasing the addition of nano silica suspension from NS0 to NS400 (Fig.1a). The sand values varied from 96.94 to $99.51 \%$. While, the silt percentage increased with increasing nano-silica up to NS200 and then decreased with increasing the treatments. The increase of silt fraction can be explained by the decrease of sand content, meanwhile the increased of clay fraction content has significant effect on the reduction of silt fraction, especially at NS300 and NS400 rates. In contrast, the clay percentage was increased with increase the suspension content of the nano silica. This was due to the added nano-silica which increase clay content which its granules less than $2 \mu$. These results was accordance with the results obtained by Liu and Lal (2012).

The nano-silica treatment has insignificant effect on bulk density, while the effect on soil porosity was significant (Table 1). Fig. (1d) showed that no significant differences were found for the effect of nano-silica on bulk density, but a negative line trend was found where the bulk density increase with increasing the treatments. The bulk density values were varied from $1.56 \mathrm{~g} \mathrm{~cm}^{-3}$ at (NS400) and $1.613 \mathrm{~g} \mathrm{~cm}^{-3}$ at (NS0). These

Results are not compatible with clay results. This means that the effect of nano-silica on the bulk density appears at the higher application rats added to the soil. The results of the nano-

silica treatments on porosity is presented in figure (1d). The results revealed significant differences between applied nano silica treatments. The porosity values of the soil increased with increasing the treatments. The porosity values ranged between 26.1 and 32.02 at NS0 and NS400, respectively. These increases in porosity is attributed to the increase in the proportion of soil granules less than $2 \mu$ (clay fraction). These results are in agreement with finding of Sharifn and Abbasi (2016) and Zhang (2007) in their study on the effect of nanoclay particles on some physical and mechanical properties of soils. 

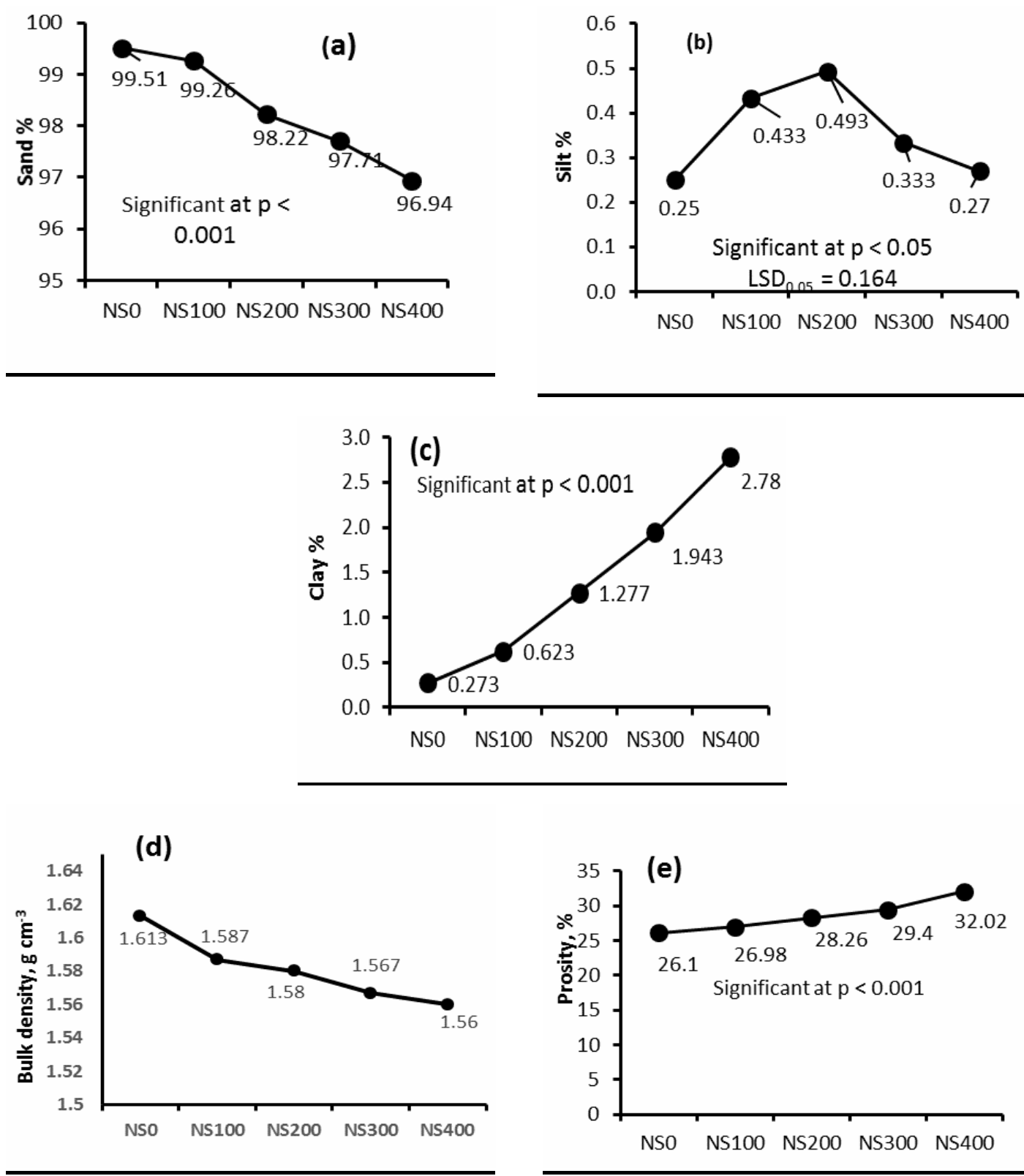

Nano-silica concentration, $\mathrm{mg} \mathrm{kg}^{-1}$

Fig. 1. The changes in sand\% (a), silt\% (b), clay\% (c), bulk density (d), and porosity\% under the effect of Nano-silica suspension $0,100,200,300$ and $400, \mathrm{mg} \mathrm{kg}^{-1}$ application rates to the soil before cultivation of bean plant

They mentioned that the nano particle has significant effect on behavior of physical and chemical properties of the soil. In the same concept, Assaedi et al. (2015) pointed to the application of nano-clay at level $2 \%$ decreased the porosity and increased water absorption of soil.

Variance analyses of saturation\% (SP), particle density, surface area, and CEC properties of soil under the effects of Nano-silica levels are presented in Table found in the of nano-silica treatments to saturation\% $(\mathrm{p}<0.001)$, surface area $(\mathrm{p}<0.05)$, cation exchangeable capacity (CEC) $\quad(\mathrm{p}<0.001)$, of soil. Whereas insignificant effect on particle density by Nano-silica ( $p$ $<0.05)$. All these parameters depend on the clay content after the application nano-silica treatments.

Fig. $2(\mathrm{a}, \mathrm{b}, \mathrm{c})$ showed the saturation percentage, surface area and CEC of the soil after harvesting of bean

(2). Results showed that the significant effects were 
Table 2. Mean of square of saturation\%, particle density $\left(\mathrm{g} \mathrm{m}^{-3}\right)$, surface area $\left(\mathrm{m}^{2} \mathrm{~g}^{-1)}, \mathrm{CEC}\left(\mathrm{cmol}_{\mathrm{c}} \mathrm{kg}^{-1}\right)\right.$ of the $^{-1}$ soil and yield ( $\mathrm{g} \mathrm{plant}^{-1}$ ) of pean under the effect of different rates of Nano silica amendment and after peans harvesting

\begin{tabular}{|c|c|c|c|c|c|}
\hline \multirow[t]{2}{*}{ Source of variance } & \multirow{2}{*}{$\begin{array}{l}\text { Degree of } \\
\text { freedom }\end{array}$} & \multicolumn{4}{|c|}{ Mean summation square } \\
\hline & & $\begin{array}{c}\text { Saturation } \\
(\%)\end{array}$ & $\begin{array}{l}\text { Particle } \\
\text { density } \\
\left(\mathrm{g} \mathrm{cm}^{-3}\right)\end{array}$ & $\begin{array}{l}\text { Surface area } \\
\qquad\left(\mathrm{m}^{2} \mathrm{~g}^{-1}\right)\end{array}$ & $\begin{array}{c}\text { CEC, } \\
\left(\mathrm{cmol}_{\mathrm{c}} \mathrm{kg}^{-1}\right)\end{array}$ \\
\hline Replication & 2 & 0.0012 & 0.0034 & 666.4013 & 0.0102 \\
\hline Nano silica treatment & 4 & $18.4164 * * *$ & 0.0048 & $3212.9264 *$ & $0.5812 * * *$ \\
\hline Error & 8 & 0.0228 & 0.0019 & 463.7941 & 0.0048 \\
\hline
\end{tabular}

$*, * * *$ : significant at $\mathrm{p}<0.05$ and $\mathrm{p}<0.001$ levels of probability, respectively.
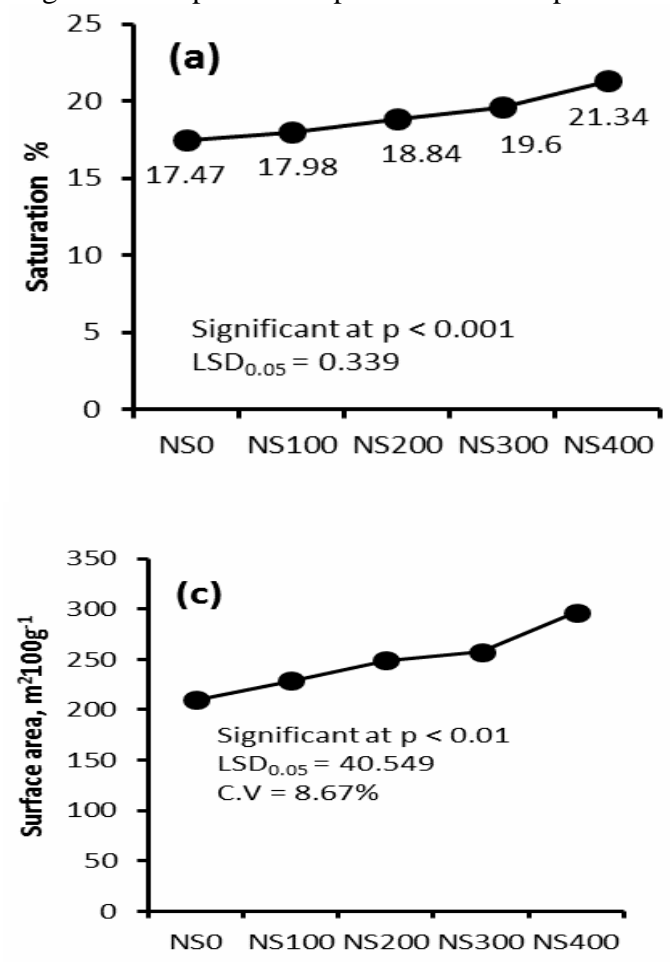
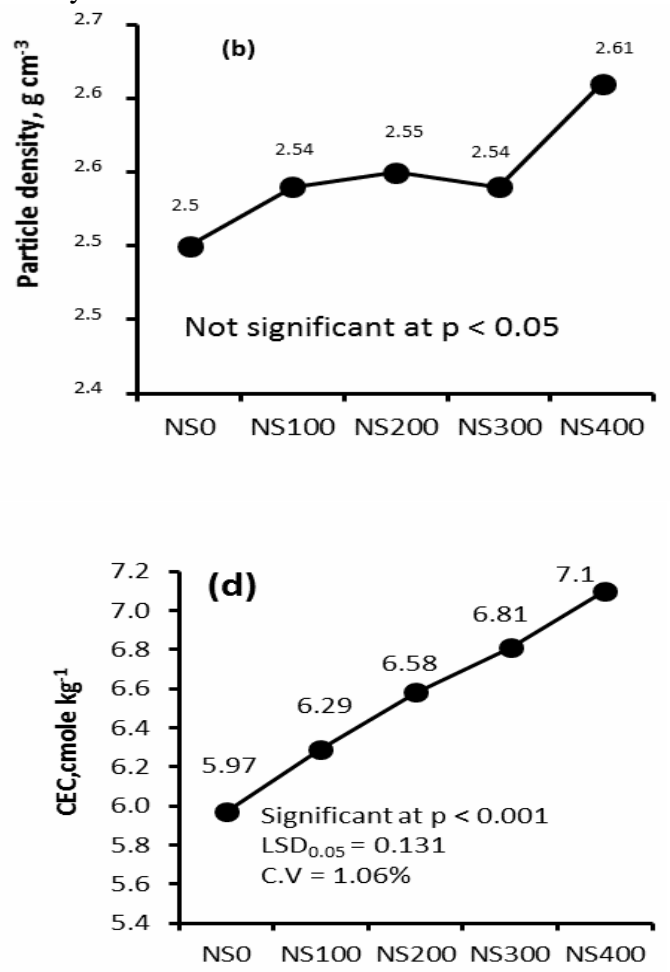

Nano-silica concentration $\mathrm{mg} \mathrm{kg}^{-1}$

Fig. 2. The changes in saturation $\%$ (a), particle density, $\mathrm{g} \mathrm{cm}^{-3}$ (b), surface area, $\mathrm{m}^{2} / 100 \mathrm{~g}$ (c), and cation exchangeable capacity $(\mathrm{CEC}), \mathrm{Cmole}_{\mathrm{c}} \mathrm{kg}^{-1}(\mathrm{~d})$ under the effect of Nano-silica suspension $(0,100,200,300$ and $400 \mathrm{mg} \mathrm{kg}^{-1}$ application rates

treating with different nano-silica concentrations. The values of SP, SA and CEC increased significantly with an upward trend with increasing the Nano silica concentration. The SP, SA and CEC ranged between $17.47-21.34 \%, 209.57-296.47 \mathrm{~m}^{2} \mathrm{~g}^{-1}$ and 5.97-7.10 Cmole $\mathrm{kg}^{-1}$, respectively. The increases in these properties are due to the increase in the percentage of clay in the soil due to the addition of nano-silica whereas, the SP, PD, SA and CEC are increased with increasing the amount of clay. All these parameter are correlated together and with clay content. These results are in agreement with Lambooy (1984) on their study on the relationship between cation exchange capacity, clay content and water retention of Highveld soils in South African where he showed that the CEC increased with increasing the clay content. Also, Xiaochuan and Kai. (2014) studied the effects of nano-silica on the physical and mechanical properties of silty clay through scanning electron microscopy and a series of tests measuring specific gravity, liquid and plastic limits, uniaxial compression, and frost heave. They indicated that increasing nano-silica concentration increased the plastic and liquid limits of the clay as well as its uniaxial compression strength, but decreased the amount of frost heave produced. However, there was no change in the specific gravity of the clay sample. 
Further, Nano-silica had no effect on the composition of the clay sample but reduced its average pore size, making its structure uniform. In the same context, Lal (2008) pointed the use of Nanomaterial increased $\mathrm{pH}$ and soil fertility, improved soil physical structure, and reduced mobility, availability and toxicity of heavy metals and other environmental factors and those that will stabilize the soil components and subsides the erosion in the mining pick.

In addition, the table (3) showed analysis of variance of other chemical properties of soil under the effect of five nano-silica levels. The results showed that the significant effects were found among nano-silica treatments for EC $(0.001), \mathrm{pH}(0.001)$, soluble $\mathrm{Ca}$ $(0.001)$ and $\mathrm{Mg}(0.001)$ and SAR $(\mathrm{p}<0.05)$, while the effect on soluble $\mathrm{Na}$ was insignificant (Table 3 ).

This means that the nano-silica has effect on chemical properties of the soil. These results are in agreement with that obtained by Lal (2008) in their study on nanomaterials on soil $\mathrm{pH}$ and soil fertility, improved soil physical structure, and reduced mobility, availability and toxicity of heavy metals and other environmental factors.

Also, a significant effect of different treatments on EC was found during the study (Fig. 3a). However, the highest value of EC $\left(2.55 \mathrm{dS} \mathrm{m}{ }^{1}\right)$ was obtained at NS0 and lowest $\left(1.8 \mathrm{dS} \mathrm{m}^{-1}\right)$ at NS400. The values of EC decreased with the increasing nano-silica levels. Decreases in salts may be attributed to the ability of nano-silica to react with saline elements and precipitate them in the insoluble salts form.

On the other hand, comparing the means of $\mathrm{pH}$ values under the effect of nano-silica treatments (Fig $3 \mathrm{~b})$ noticed that a significant effect of the treatments on $\mathrm{pH}$. The $\mathrm{pH}$ ranged between 6.72 at NS200 and 7 at NS300 and NS400 and significant differences between NS200 and the other treatments. The pH is in the appropriate range for plant growth. Acidity decreases with increasing application rate from zero to $200 \mathrm{mg} \mathrm{kg}^{-}$ ${ }^{1}$ and then rising again to the level of stability. These results are attributed to the ability of the soil as a regulator to prevent the significant change in acidity $(\mathrm{pH})$. These results are consistent with studies of Lal (2008).

Fig (3c) showed that the treatments had a significant effect on soluble $\mathrm{Ca}^{2+}$. A significant differences were found between all treatments. The $\mathrm{Ca}^{2+}$ values decreased with decreasing nano-silica treatments. The values differed from 1.95 at NS0 to $1.28 \mathrm{mmol} \mathrm{L}^{-1}$ at NS400 treatments. The values take the same direction of EC property.

five rates of Nano-silica $(0,100,200,300$ and 400 $\mathrm{mg} \mathrm{kg}^{-1}$ soil) which added to the soil before cultivation of bean plant five rates of Nano-silica $(0,100,200,300$ and $400 \mathrm{mg} \mathrm{kg}^{-1}$ soil) which added to the soil before cultivation of bean plant five rates of Nano-silica $(0$, $100,200,300$ and $400 \mathrm{mg} \mathrm{kg}^{-1}$ soil) which added to the soil before cultivation of bean plant five rates of Nanosilica $\left(0,100,200,300\right.$ and $400 \mathrm{mg} \mathrm{kg}^{-1}$ soil) which added to the soil before cultivation of bean plant five rates of Nano-silica $\left(0,100,200,300\right.$ and $400 \mathrm{mg} \mathrm{kg}^{-1}$ soil) which added to the soil before cultivation of bean plant five rates of Nano-silica $(0,100,200,300$ and 400 $\mathrm{mg} \mathrm{kg}^{-1}$ soil) which added to the soil before cultivation of bean plant five rates of Nano-silica (0, 100, 200, 300 and $400 \mathrm{mg} \mathrm{kg}^{-1}$ soil) which added to the soil before cultivation of bean plant five rates of Nano-silica ( 0 , $100,200,300$ and $400 \mathrm{mg} \mathrm{kg}^{-1}$ soil) which added to the soil before cultivation of bean plant five rates of Nanosilica $\left(0,100,200,300\right.$ and $400 \mathrm{mg} \mathrm{kg}^{-1}$ soil) which added to the soil before cultivation of bean plant five rates of Nano-silica $\left(0,100,200,300\right.$ and $400 \mathrm{mg} \mathrm{kg}^{-1}$ soil) which added to the soil before cultivation of bean plant five rates of Nano-silica $(0,100,200,300$ and 400 $\mathrm{mg} \mathrm{kg}{ }^{-1}$ soil) which added to the soil before cultivation of bean plant five rates of Nano-silica (0, 100, 200, 300 and $400 \mathrm{mg} \mathrm{kg}^{-1}$ soil) which added to the soil before cultivation of bean plant Similarly, for soluble $\mathrm{Mg}^{2+}$ (Fig. 3d) the highest value was recorded when used NS0 (1.947 $\mathrm{mmol} \mathrm{L}^{-1}$ ) and low value recorded 1.28 mmole $\mathrm{L}^{-1}$ at NS400, on the other hand, $\mathrm{Ca}^{2+}$ values take the same trend of EC. These results are in agreement with that obtained by Mohammadi and Niazian, (2013). They indicated that the use of nano-technology in agricultural science and its application in tillage for improving the physical properties and mechanical issues has grown substantially.

Fig. (4a) showed that there were non-significant effect of different Nano-silica treatments on soluble $\mathrm{Na}^{+}$. The soil treated with NS0 treatment showed lower $\mathrm{Na}^{+}$value $\left(1.90\right.$ mmole $\left.\mathrm{L}^{-1}\right)$ and the highest value was 2.26 mmole $\mathrm{L}^{-1}$ at NS400 treatment. The $\mathrm{Na}^{+}$ concentration increased with increasing nano-silica treatments. The results showed that the values of $\mathrm{Na}^{+}$ were the opposite of the values of $\mathrm{EC}, \mathrm{Ca}^{2+}$ and $\mathrm{Mg}^{2+}$ in soil. The results also, pointed that the increasing of $\mathrm{Na}^{+}$ with nano-silica may be due to the reaction of Nano silica with soluble $\mathrm{Ca}^{2+}$ and $\mathrm{Mg}^{2+}$ and precipitate them in the form of silicate.

A significant effect of different nano-silica treatments on Sodium adsorption ratio (SAR) was found during the study (Fig. 4b). However, The SAR values increased with increasing the treatment of nano-silica. The increasing values were due to the increasing of $\mathrm{Na}^{+}$ and decreasing of $\mathrm{Ca}^{2+}$ and $\mathrm{Mg}^{2+}$. 
Table 3. Mean of square of EC $\left(\mathrm{dS} \mathrm{m}^{-1)}, \mathrm{pH}\right.$, sodium $\left(\mathrm{mmol}^{-1}\right)$, calcium $\left(\mathrm{mmol}^{-1}\right)$, magnesium $\left(\mathrm{mmol}^{\mathrm{l}}\right)$ and SAR of the soil and yield ( g plant $^{-1}$ ) of cucumber under the effect of different rates of Nano-silica amendment and after pean harvesting

\begin{tabular}{|c|c|c|c|c|c|c|c|}
\hline \multirow[t]{3}{*}{ Source of variance } & \multirow{3}{*}{$\begin{array}{l}\text { Degree of } \\
\text { freedom }\end{array}$} & \multicolumn{6}{|c|}{ Mean summation square } \\
\hline & & \multirow{2}{*}{$\begin{array}{c}\mathrm{EC} \\
\left(\mathrm{dS} \mathrm{m}^{-1}\right)\end{array}$} & \multirow[t]{2}{*}{ pH } & \multicolumn{3}{|c|}{ Soluble cations, mmole $\mathrm{l}^{-1}$} & \multirow[t]{2}{*}{ SAR } \\
\hline & & & & $\begin{array}{c}\text { Calcium } \\
\left(\text { mmole }^{-1}\right)\end{array}$ & $\begin{array}{c}\text { Magnesium } \\
\left(\text { mmole }^{-1}\right)\end{array}$ & $\begin{array}{c}\text { Sodium } \\
\left(\mathrm{mmol} \mathrm{l}^{-1}\right)\end{array}$ & \\
\hline Replication & 2 & 0.0050 & 0.0008 & 0.0003 & 0.0001 & 0.0163 & 0.0100 \\
\hline Nano silica treatment & 4 & $0.2579 * *$ & $0.0465 * *$ & $0.2102 * * *$ & $0.1951 * * *$ & $0.0578^{\mathrm{NS}}$ & $0.1238^{*}$ \\
\hline Error & 8 & 0.01055 & 0.0040 & 0.0002 & 0.0021 & 0.0425 & 0.0274 \\
\hline
\end{tabular}

$*, * *, * * *, * * * *$ : significant at $\mathrm{p}<0.05, \mathrm{p}<0.01, \mathrm{p}<0.001$ and $\mathrm{p}<0.0001$ levels of probability, respectively. NS: not significant at $\mathrm{p}<0.05$.
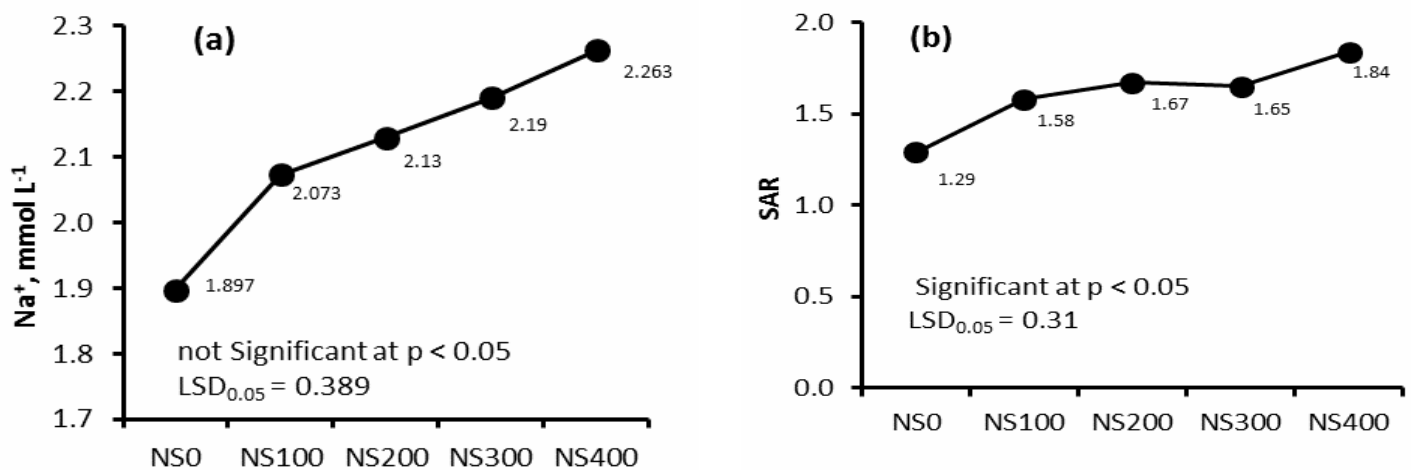

Nano-silica concentration $\mathrm{mg} \mathrm{kg}^{-1}$

Fig. 4. The changes in $\mathrm{Na}^{+}$(a) SAR (d) under the effect of nano-silica suspension (NS0(0), NS100(100), NS200 (200), NS300 (300) and NS400 (400, $\left.\mathrm{mg} \mathrm{kg}^{-1}\right)$ applied to the soil

Table 3. Mean of square of total $\mathrm{N} \%$, available Si mg kg-1 in soil after pean harvesting and the yield $\left(\mathrm{g} \mathrm{plant}^{-1}\right)$ of pean under the effect of different rates of Nano-silica amendment and after

\begin{tabular}{lcccc}
\hline Source of variance & $\begin{array}{c}\text { Degree of } \\
\text { freedom }\end{array}$ & Total N\% & $\begin{array}{c}\text { Mean summation square } \\
\text { Avaliable Si, } \\
\text { mg kg }^{-\mathbf{1}}\end{array}$ & $\begin{array}{c}\text { Yield } \\
\mathbf{g ~ p l a n t}^{\mathbf{1}}\end{array}$ \\
Replication & 2 & 0.00000020 & 38.58642 & 3968.395 \\
Nano silica treatment & 4 & $0.00005477^{* * *}$ & $15404.58077^{* * *}$ & $385051.475^{* * *}$ \\
Error & 8 & 0.00000012 & 18.50091 & 1789.193 \\
\hline
\end{tabular}

*,**, ***, ****: significant at $\mathrm{p}<0.05, \mathrm{p}<0.01, \mathrm{p}<0.001$ and $\mathrm{p}<0.0001$ levels of probability, respectively. NS: not significant at $\mathrm{p}<0.05$.

Variance analyses of total soil nitrogen and available soil $\mathrm{Si}$ of the soil under the effects of nano-silica levels are presented in Table (4). The results revealed that, there were significant differences between means of total N, available $\mathrm{Si}$ in the studied soil, and the yield of pean $\left(\mathrm{g} \mathrm{plant}^{-1}\right)$ under the effect of nano-silica. The data revealed that the nano-silica has effect on the yield of pean crop. The result of yield is in agreement of Suriyaprabha (2013) in his study on the role of Nano silica on improving the corn growth. And also, with the study of Amrullah et al. (2015) which indicated the positive effect of Nano silica on growth, yield and yield components of rice compared to non-treatment plants with nano silica.

The total $\mathrm{N}$ varied between 0.02 at NS0 to $0.03 \%$ at NS200 treatment (Fig. 5a). Also, the results showed that the total N\% increased with increasing NS up to 400 ppm and then deceased with increasing the treatments from 200 to $400 \mathrm{ppm}$ (Fig. 5a). The increasing of nitrogen in the soil reflected on the plant production, which means that nano-silica improved the fertility of the soil according the obtained result and the finding of Lal (2008). 

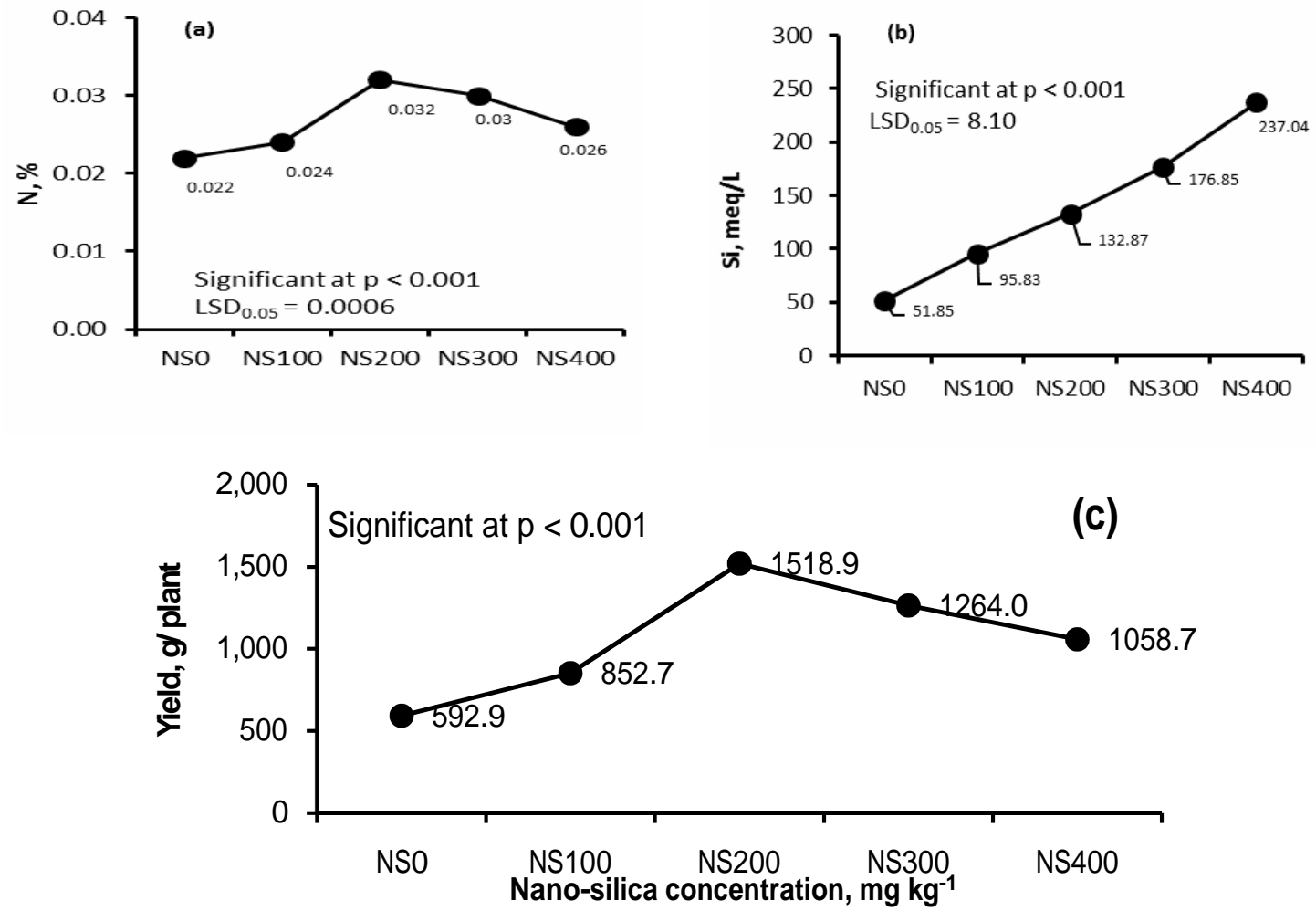

Fig. 5. The effect of Nano-silica suspension (NS0(0), NS100(100), NS200 (200), NS300 (300) and NS400 (400, mg kg-1) application to the soil on total nitrogen\% (N,\%), soluble $\mathrm{Si}(\mathrm{Si}, \mathrm{meq} / \mathrm{L})$, and the yield of bean crop (Yield, g/plant)

The results in figure $(5 \mathrm{~b})$ clarified that, available $\mathrm{Si}$ has been influenced by nano silica rates, where the values of $\mathrm{Si}$ ranged between 51.85 to $237.04 \mathrm{mg} \mathrm{kg}^{-1}$ when the plants treated with NS0 and NS400 treatments, respectively. The application of nano-silica increased available Si (Fig. 5b).

Nano-silica impact on crop yield: The result in figure (5c) showed that the yield increased with increasing the Nano-silica treatments up to NS200 and then decreased with increasing the application rates of nano-silica. The same trend found on the total nitrogen content in the soil was observed on the yield (Fig. 5c). According these results, we can conclude that the application of nano-silica in soil has positive effect on nutrient elements such as nitrogen which reflected on the cultivated plant. In the same context, Yuvakkumar et al. (2011) indicated that the introduction of nanoparticles into plants might have significant impact and thus, it can be used for agricultural applications for better growth and yield.

\section{CONCLUSIONS}

It can be concluded that the addition of nano-silica to soil raised the values content of clay in soil, consequently, the saturation percentage, particle

density, surface area, cation exchange capacity, porosity, sodium adsorption ratio, and soluble sodium content increased. The improvement of these properties increased the total nitrogen in the soil and increased the yield of bean at NS200 treatment. The use of nano-silica particles in soil reduced the average of sand and silt particles, bulk density, EC, Soluble $\mathrm{Ca}^{2+}$ and $\mathrm{Mg}^{2+}$.

\section{ACKNOWLEDGMENT}

The researcher would like to thank Professor Mohamed Mohamed Elgarawany at the Agricultural and Veterinary Research and Training Station, King Faisal University, Kingdom of Saudi Arabia for his support, guidance and review to complete this work.

\section{REFERENCES}

Amrullah, D. Sopandie, Sugianta and A. Junaedi. 2015. Influence of Nano-silica on the Growth of Rice Plant (Oryza sativa L.). Asian J. Agric Res, 9: 33-37.

Assaedi, H., F.U.A. Shaikh, I. M. Low. 2015. Effect of Nanoclay on mechanical and thermal properties of geopolymer. Journal of Asian Ceramic Societies.4(1):19-28.

Ayres, A.S. 1966. Calcium silicate slag as a growth stimulator for sugarcane on low silicon soils', Soil Sci. 101: 216227. 
Datnoff, E. L., C. W. Deren and G. H. Snyder. 1997. Silicon fertilization for disease management of rice in Florida. Crop Prot. 16: 525-531.

Dinda, A.K., C. K. Prashant, S. Naqvi, J. Unnithan, M. Samim and A. Maitra. 2012. Curcumin loaded organically modified silica (ORMOSIL)Nanoparticle; a novel agent for cancer therapy', Int. J. Nanotechnol. 9: 862-871.

Epstein, E. 1999. Silicon. Ann. Rev. Plant Physiol. Plant Mol. Biol. 50: 641-664. doi:10.1146/annurev.arplant.50.1.641

Feynman, R P. 1960. There's plenty of room at the bottom. Eng Sci. 23:22-36.

Gholami, A., S. Shahsavani, S. Nezarat. 2009. The effect of plant growth promoting rhizobacteria (PGPR) on germination, seedling growth and yield of maize. Int. J. Biol. Life Sci. 1: 35-40

Karunakaran, G., R. Suriyaprabha and P. Manivasakan. 2013. Effect of Nano-silica and silicon sources on plant growth promoting rhizobacteria, soil nutrients and maize seed germination.IET Nano-silica. 7(3):70-77.

Khakipour, N., K. Khavazi, H. Mojallali, E. Pazira and H H. Asadirahmani. 2008. Production of auxin hormone by fluorescent Pseudomonads', American-Eurasian J. Agric. Environ. Sci. 4: 687-692.

Kim J. 2012. Preface," in Advances in Nanotechnology And the Environment, J. Kim, Ed., Pan Stanford Publishing, Singapore, Singapore, View at Google Scholar.

Klute, A., G. S. Campbell, D. R. Nielsen, R. D. Jackson. 1986. Methods of soil analysis: Part 1 Physical and Mineralogical Methods Second Edition Monograph No. 9, ASSS, Madison, WI, USA.

Lal, R. 2008. Promise and limitations of soils to minimize climate change. Journal of Soil and Water Conservation. 63 (4): 113-118.

Lambooy, A. M. 1984. Relationship between cation exchange capacity, clay content and water retention of Highveld soils. South African Journal of Plant and Soil. 1(2) 33-38.

Liu, R. and R. Lal. 2012. Nanoenhanced Materials for Reclamation of mine lands and other degraded Soils: A Review. Volume 2012. Article ID. 461468. 18 pages.

Ma, J. F. 2004. Role of silicon in enhancing the resistance of plants to biotic and abiotic stresses', Soil Sci. Plant Nutr. 50: $11-18$

Mohammadi, M. and M. Niazian. 2013. Investigation of Nano-clay effect on geotechnical properties of rasht clay. International journal of advanced scientific and technical research. 3(3):37- 46.
Ort?z-Castro, R., E. Valencia-Cantero, J. L?pez-Bucio. 2008. Plant growth promotion by Bacillus megaterium involves cytokinin signaling. Plant Signal Behav. 3: 263-265

Page, A. L., R. H. Miller, R D. Keeny. 1982. Methods of soil analysis: Part 2 chemical and biochemical properties $\left(2^{\text {nd }}\right.$ edition). Monograph No. 9, ASSS, Madison, WI, USA.

Paulkumar, K., R. Arunachalam and G. Annadurai. 2011. Biomedical applications of organically modified bioconjugated silica Nanoparticles. Int. J. Nanotechnol. 8: 653-66311

SAS institute. 2001. SAS for windows, SAS user' guide: Statistics. Version 8.0e. SAS inst., Inc., Cary, North Carolina.

Savant, N. K., G. H. Korndorfer, L. E. Datnoff and G. H. Snyder.1999. Silicon nutrition and sugarcane production: a review. J. Plant Nutr. 22: 1853-1903

Sharifnasab, H and N. Abbasi. 2016. Effect of Nanoclay particles on some physical and mechanical properties of soils. Journal of Agricultural Machinery. 6(1):250-258.

Steel, R. G. D. and J. H. Torries. 1980. Principle and procedure of statistical a biomaterial approach. $2^{\text {nd }}$ edn. McGrow-Hill. New York, USA. ISBN: 0-07060-926-8.

Suriyaprabha, R., G. Karunakaran, R. Yuvakkumar and N. Kannan. 2013. Application of Silica Nanoparticles for Increased Silica Availability in Maize. IET Nanobiotectechnol. 1-5.

Theron, J., J. A. Walker, and T. E. Cloete. 2008. Nanotechnology and water treatment: applications and emerging opportunities. Critical Reviews in Microbiology. 34 (1): 43-69.

Xiaochuan, R. and H. Kai. 2014. Effect of Nano-silica on the Physical and Mechanical Properties of Silty Clay. Nanoscience and Nanotechnology Letters. 6(11): 10101013.

Yuvakkumar, R., V. Elango, V. Rajendran, N. S. Kannan and P. P.Prabu. 2011. Influence of Nano-silica powder on the growth of maize crop (Zea mays L.). Int. J. Green Nanotechnol. 3: 180-190

Zhang, G. 2007. Soil Nano particles and their influence on engineering properties of soils. Advances in Measurement and Modeling of soil Behavior. 'https://doi.org/10.1061/40917/(236)37. Published online: June 20, 2012

Zhang,J.G, T. Germanie,A. J. Whittle and C. Ladd. 2004.Index properties of a highly weathered old alluvium. Geotechnique. 42(7):441-451. 


\section{الملخص العربي}

\section{رصد التغيرات في الخصائص الكيميائية والفيزيائية في التربة المزروعة بنبات الفاصوليا}

\section{تحت تأثير النانو السيليكا}

$$
\text { عبد الله بن حسن السعيدي }
$$

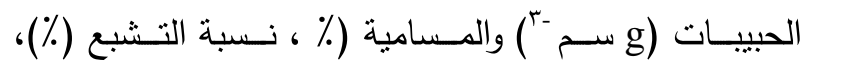

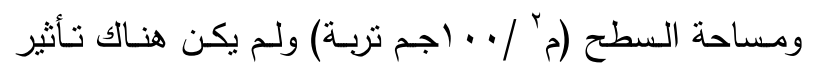

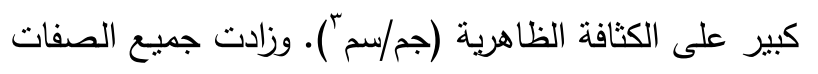

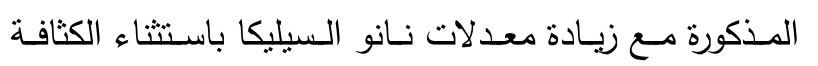

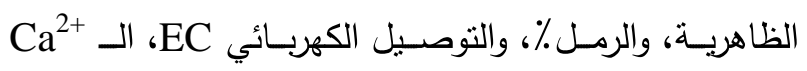

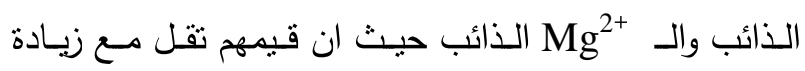
معدلات النانو السيليكا. وبينت النتائج ايضا أنه ليس هناك اتجاه معين لدرجة الحموضة pH. ووجد أن النتروجين الكلي

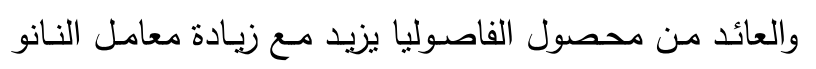

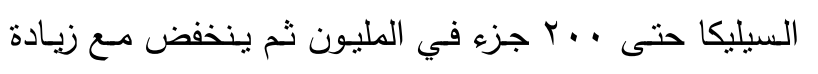

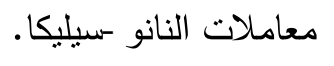

أجريت هذه التجربة في البيت المحمي في محطة التدريب والبحوث الزراعية والبيطرية، جامعة الملك فيصل، بالأحساء،

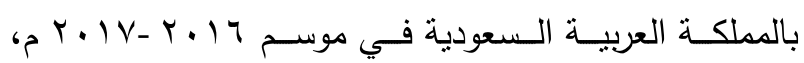

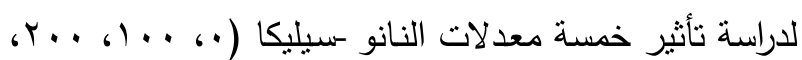

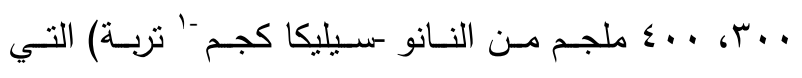
أضيفت إلى التربة قبل زراعة نبات الفاصوليا على بعض من من من

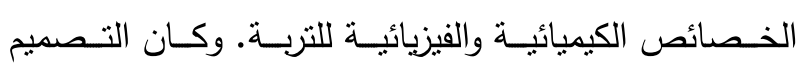
المستخدم القطاعـات كاملـة العشوائية في ثلاثتة مكـرات.

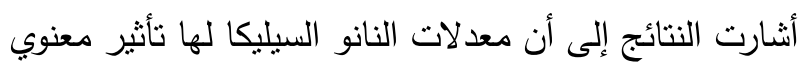

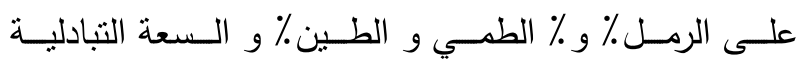
الكاتيونية (سيمول من الكاتيونات كجم -' من التربة) و كثنافة ولرية 